\title{
The Denial of the Personal, the Preservation of the Status Quo in Teacher Education
}

\author{
Ardra L. Cole \\ OISE, University of Toronto
}

\begin{abstract}
This paper presents two stories of learning and teaching. Through the stories, the author explores the relationship between personal historybased learning and teaching practice and advocates a process of reflexive inquiry for teacher learning and teacher education. A major focus is on how a curriculum and pedagogy of reflexive inquiry can transform, deepen and broaden conceptions of teacher education as well as make a difference in how teachers see and express themselves in educational contexts. The author also describes the meanings and implications of a personal history pedagogy for teacher education institutions as well as the contextual changes required for such transformative practices to be adopted.
\end{abstract}

\section{Introduction}

I write this on a bitterly cold morning in late winter; the steam from my mug of hot coffee wending its way upward both suggesting and providing comfort and warmth. I invite you to join me as I tell a couple of stories. These are stories of learning, stories of teaching; they are also stories of teacher education. Because one good story leads to another and one meaning connects with another, I expect that my stories will connect with your stories, and we will recognize that our stories make up the grand narrative of education. Telling teaching and learning stories provides a way in, a point of connection between us, and a commonplace to explore issues related to teaching and teacher education. So settle into a comfortable chair, wrap your hands around a mug of your favourite hot beverage, and I will begin.

\section{First Story: School Rules?}

"Cry Mary", came the expected sing-songy taunt from my mother as tears of anger and hurt involuntarily and uncontrollably spilled down my cheeks. One of my schoolmates had teased me to tears about my weight. It didn't take much to make me cry-an off-handed comment, a suspicious snicker, playful (?) name calling. My brother knew how to make me cry almost on cue. "Nice dress", he would murmur on his way out the door, his sarcasm jabbing me as he passed me

Andra Cole is Professor and Co-director of the Centre for Arts-informed Research in the Department of Adult Education and Counselling Psychology at the Ontario Institute for Studies in Education of the University of Toronto. 
in the hallway. "Mum got it in the Chubby Clothes Department at Eaton's. The only place she could find something to fit you, you tub of lard. Took the tags off so you wouldn’t know." And he was gone. "M-u-u-m”, I'd blubber, almost choking on the hatred building like bile in my mouth for the clothes that, only moments ago, I had loved and felt proud of, and feeling overwrought by the prospect of my mother's betrayal. "Tim's telling lies", I'd report, half-hoping to have that confirmed. "For God's sake, a person can't even look at you sideways without you crying. Don't be so bloody sensitive”, would come her evasive and uncomforting response.

My mother's taunts and unconsoling words were intended to toughen me up. Being a cry baby was not a "good" thing in her view. Her efforts failed. I am still a cry baby. Still, no matter how hard I try, my first involuntary and uncontrollable expression of anger or emotional hurt is tears. "Cry Mary", I hear in my mind's ear as I will the tears to stop. "Don't be so bloody sensitive”, my mother's voice half chastizes, half cautions me. I can't help it.

In my early years of school, before my attention was diverted to my own adolescent curriculum which had little, if anything, to do with academic achievement, I was a model student, a teacher's pet. I chalked up gold stars and prizes for spelling, creative writing, and memory work. I was usually one of the first to complete her seat work. I could always be counted on to read the "hard parts” well during our regular round robin reading exercises. My work was always among that displayed on bulletin boards for Parent Night or other such occasions when teachers put their best feet forward for public scrutiny. My mother never missed a Report Card Night, when teachers delivered news of students' progress to attending parents. She was there every Parent Day-one afternoon each term when spic and span classrooms and spic and span teachers and students were put on display for spic and span parents who sat uncomfortably in tiny chairs lined around the perimeter of the classroom. For hours they sat, like students themselves again, stifling twitters of humor or embarrassment when some child made an obvious error, or not so subtly expressing smug satisfaction and pride when one of their children delivered a correct answer or received praise from the teacher.

My mother was social convenor for the Home and School Association. She organized social and fund raising functions and coordinated the home-school communication pertinent to those functions. She had high visibility in the school and was, therefore, seen as an involved and caring parent. I think that made a difference in how I was treated by the teachers. My appearance was always impeccable (as was my mother's) and I was well groomed in good manners and obedience. All of this pushed me forward toward success and, consequently, my experiences of school were undeniably happy.

Only two things played on my mind enough to interrupt my ultimate elation: one was the regularly doled out punishment I received for talking; the other was my awareness that school wasn't for everyone the safe and happy place it was for me (except for those times when I was the target of someone's teasing). I couldn't bear to see the frustration and hurt on Arnold's face each time his work was returned blood stained from the teacher's red pen. "It's not fair", I'd think to 
myself and later express to my mother. "He tries so hard, much harder than I do. He can't help it if he can't do the work." Each time it was Donald's turn to read aloud, I held my breath through each painful hour-long moment of silent anticipation as he mustered up all the will he could find to force out those stubborn sounds. "C-c-c-come, M-M-M-M-Mother. . . ”, he'd stammer, his face as red with humiliation and frustration as the page in Arnold's workbook. I sighed in defeat each time Andrew returned to his seat instructed to re-do his work, "neatly this time". Out of the corner of my teary eye, as I raced easily through line after line of perfectly formed "sticks and balls" of various sizes and angles, I watched him-head bent low, face contorted in determination and shame, tongue stretched out one side of his mouth urging him along, tears and snot dripping onto the page, sweaty hands trying to wipe the page clean instead creating dirty smudges and making matters worse, almost certainly ensuring another, louder "neatly this time!”. I flinched with every contact the strap made on Colin's outstretched palm, regardless that he always re-entered the room with a grin on his face and a swagger in his step. His red-rimmed eyes always gave him away. My brothers' outgrown clothes, discretely passed along to save embarrassment, replaced some of Mark's tattered and threadbare ones so that the other kids would stop teasing him behind his back about being poor. I hated kids' teasing. So what if Mark is poor? So what if am fat? So what if Arnold is slow to learn? So what if I am fast? So what if Andrew is messy? So what if I am neat? So what if David stutters? So what if I am a good reader? So what if Colin behaves in ways that make the teacher resort to beating him? Is that the only resort? I will never get a beating. So what does that make me? "It's just not fair", was my eternal plea. "It's just not fair."

Around our kitchen table meaning was given to all that was good, bad, and indifferent in my mother's world as she and her friends philosophized and analyzed their way through bottomless cups of tea and countless packs of Black Cat cigarettes. I'd listen and watch as smoke, slowly but confidently released through crimson- and cotton candy-coloured lips, enwreathed words of blessing or blame. I'd protest when I felt someone was being gossiped about or picked on or otherwise criticized. "Oh, there she is, the great defender", would come the half criticism, half comment each time I predictably rose to the defense of any absent someone. "There must be a good reason", was my usual retort. "We don't know the whole story." I couldn't tolerate the prospect of someone being unfairly judged or treated, especially without knowing the "whole story". Still can't.

Years later again, as a Special Education Resource Teacher at a girls reform school, I reckoned back once more to my early years of school. I listened to countless stories in which school was experienced and depicted not as the safe and inviting place I knew but as the kind of threatening and punishing place it was for many of my classmates.

Fifteen year old Tammy, outer shell toughened over the years to deflect or soften the barrage of hardships that came her way, could barely read text written for someone at a Grade 3 reading level. "I hate school Miss. There's no way they're gonna make me go back. I'll just keep runnin' till I'm sixteen and they can’t make me no more.” Edna's reading level was lower than Tammy’s. "My 
teacher used to say that I was courageable or some stupid thing. Who cares? All I know is that school is the pits. I got so bored sittin' outside the principal's office all the time I set the school on fire. Dumb teachers. And here I am. I ain't goin' back. No one can make me.” Kathy, in contrast, scored above average on all of the achievement tests. "I love school. I really do. Trouble is I can't seem to behave myself when I'm there, when I do get there, that is. I spend half my time at my dad's place and when he's sober that's good. But when he gets drunk he beats me if I don't run first. So a lot of time I'm on the run. When I'm at my mum's place it's okay until she brings a new boyfriend home and sometimes things can get pretty rough so I run from there. My older sister's pretty good about takin' me in but she's tryin' to get on her feet and her husband don't like me hangin' around. Teachers wouldn't understand any of that. It's easier to just make up some stupid excuse for hookin' class."

It wasn't fair when I was seven or ten; it was no fairer at seventeen or twenty or thirty; and it's not fair now that School plays favorites. Through my young and innocent eyes everyone deserved the benefit of the doubt. Through my not so young and no longer innocent but still somewhat naive eyes, they still do. I need to know the whole story-to understand not judge; to empathize, not condemn.

\section{Teaching and Knowing Who We Are}

My learning stories/stories of learning are my memories of learning. They are my truths or, as Virginia Woolf might say, my memories are the base of my life. Like it or not, for better or worse, these memories and the experiences upon which they are based, are with me in every teaching or professional context. Sometimes they are closer to consciousness than other times; sometimes I see my learner or teacher self and like what I see; other times quite the opposite. Each time I enter a classroom, meeting, or any other formal education or professional context I take with me all that I am, where I have been, what I have done, and how I have experienced teaching, learning, and schooling. Every moment of teaching is an expression of my autobiography. Remembering and reconstructing the narratives of my life helps me to understand who I am and how I am in the world. It is the way I am able to know myself and move forward in my work. Whether we work with preschoolers or preservice teachers, in public schools or universities we all teach from our stories. We teach who we are.

Even though school was pretty much a safe place for me as a student, I vividly remember and am mindful of those for whom it was not-the Donalds and Andrews, the Marks and Colins, the Tammys and Ednas, and Kathys. I am constantly reminded of how alienating schools and classrooms are to so many people, even those who were able to successfully negotiate their way through the system to become teachers. Tammys and Ednas, Donalds and Andrews are everywhere. They occupy a good part of our public school classrooms. It is not very likely that they will become teachers themselves but those who do become teachers might remember them; those "problem students" who were so unlike themselves-the ones who were always causing and getting into trouble, wouldn't or couldn't do the work, never seemed to fit in. When the new teachers take on their new classroom responsibilities they will likely find Kathy and Mark in their 
own classrooms and they, along with Tammy and Edna, will become the new "problem students". They will be there, the textbook cases from Educational Psychology class; the ones acknowledged by other teachers as "victims" of an overextended system. And they will remain 'out there', 'over there', always as someone else's responsibility or fault if we do not encourage teachers to move closer, listen to the story, and take part in the construction of a counternarrative.

Vivian Gussin Paley, in her foreword to Ayers' The Good Preschool Teacher, posits: "There should be a sign above every classroom door that reads, 'All teachers who enter be prepared to tell your story"'. If we are to really understand teaching, to engage more fully in classrooms in holistic and authentic ways as thinking, feeling, political, relational, moral, aesthetic beings, and if we are to take seriously our responsibilities for the education of teachers, we need to understand ourselves and we need to help others do the same. To do so, we need to tell and foster the telling of stories. Teaching, then, becomes a process of reflexive inquiry and authentic practice.

As William Pinar (1981, p. 184) would say, we need to "return to [our] own situation . . . to reconstruct [our] intellectual agenda." This means understanding the formative experiences and influences that have shaped our perspectives and practices. Our stories become, in a sense, the "rules" we use to monitor our work, the "lessons" we work by. If teaching is an expression of the personal, learning about teaching becomes an autobiographical project. Understanding self as teacher is, in Pinar's (1981) words, "a precondition and concomitant condition to the understanding of others". A curriculum and pedagogy of personal history or reflexive inquiry (Cole \& Knowles, 2000; Knowles \& Cole with Presswood, 1994) is guided by a set of values, beliefs, and principles based on self-directed learning, mutual respect, the primacy of experience, relational equity, and learning as an inquiry-based educative process. It is not a tool or strategy; it is an orientation, a perspective, a practice. As such it contests much of what has come to define and be expected in teacher education programs. And speaking of rules and conformity: another story.

\section{Second Story: Learning Rules}

My fascination with written language was born and nurtured on cold winter mornings in my brothers' bedroom while we waited for the house to heat. It was there that I discovered the power and magic of words-that letters made sounds that combined to form words which, when strung together, became sentences which all made sense. The discovery was exhilarating; the possibilities endless. I was intrigued that some letters "went together" and some didn't (kind of like choosing my clothes in the morning, "Does this go Mummy?"). Sometimes a single letter formed a word; other times numerous letters were strung together and the words were longer (I especially liked those ones). Sometimes how the word was spelled was very different from how it looked. Sometimes it was very easy to figure out words and meanings; sometimes not so. I entered school with an enduring respect for the power and possibilities of words. Throughout my life, words in the form of text, written by others or myself, have inspired, supported, and sustained me. 
The structures and meanings of words and sentences held my attention throughout elementary school. I thrived on reading, spelling, and grammar. All else paled in significance. Halfway through my Primary (Kindergarten) year I was moved to Grade 1, presumably because I could already do most of what we were expected to learn in Primary. I was thrilled: Grade 1 kids sat at desks; Grade 1 kids had homework; Grade 1 kids had readers and workbooks. The prospect of having my very own reader-my own hard covered "text", the ultimate symbol of status and maturity-was alluring indeed. In my school that symbol was first manifest in The Little White House, the primer in the Ginn Basic Reading Series. To earn that status, however, one had to have completed (which meant mastered) the three soft covered preprimers in the series. (For some reason, an achievement test wasn't considered adequate. It was necessary to actually complete each story and accompanying workbook activity before moving to the next level.)

I endured through the first set of "adventures" of Tom, Betty, and Susan, their mother and father (whom they called Mother and Father instead of Mummy and Daddy), and their pets Flip and Pony along with Susan's toy Bunny. The stories in the texts seemed stilted and unrealistic, not like the ones I was used to at home. "Father! Father! Here comes Father! Come here, Tom. Come and see Father!" Nevertheless, because they were part of school and led to bigger and better things, the stories and the readers were to be taken seriously.

My task, as I saw it, was to move as quickly as possible through My Little Red, Green, and then Blue Story Books and the accompanying My Do and Learn workbooks in order to move closer to the brass ring-the hard covered reader. Everyday I read as much and completed as many workbook pages as I was permitted. My sights were set on The Little White House-the "real" reader with the hard cover and what I assumed could only be more sophisticated and complex content. The use, throughout the series, of controlled vocabulary and repetition promoted reading as an exercise rather than as something to be enjoyed. For me, the joy (of learning) was in the completion of the stories, not in the stories themselves. Thus were firmly established my understandings of the relationship (or rather the lack thereof) between school and learningunderstandings so deeply implanted in my formative years that it wasn't until graduate school that I was able to pry them loose. And so, while in school I worked diligently toward my goal, head down and mind's eye on the book ahead; outside of school I continued to develop my friendship with books and my love of reading.

Sometimes we were allowed to take our readers home to practice or show off our progress to our parents. I liked taking my reader home so that I could skip ahead. For the most part I was embarrassed by the simplistic and repetitive nature of the preprimers. (This attitude might have been fostered by my mother who would imitate me in a sing-songy voice, "To-om. Bet-ty. See Flip run."). And, while I was proud to finally earn the status symbol of the hard cover reader, it wasn't until On Cherry Street, the next one in the series, that I felt challenged and engaged.

With the First Grade Reader came complex and interesting vocabulary and sentence structures: familiar letters which, when combined, made strange new 
sounds; letters, that alone had no meaning, could change the entire meaning of a word when tacked onto the end; "silent" letters; new punctuation like apostrophes and hyphens; and delicious and sophisticated polysyllabic words like "wonderful" and "tomorrow" and "telephone". Oh how grownup and learned I felt when those words just seemed to roll off my tongue without a lump or a bump. At that point I also thrilled at the achievement of deciphering an unknown word.

On cold winter afternoons my mother would often spread a blanket on the hall floor in front of the space heater where we would sit for hours reading, sometimes silently to ourselves and sometimes aloud. To me this was a special treat and, while I'm sure my mother enjoyed certain elements of this "special" time, I have no doubt that she was all the while cursing having to "play picnic" to keep warm.

"What's this word Mummy?"

"You know that word. Look at it. What little words can you see?"

"Al-to-get-her."

"Okay, say it fast."

"Altoget-her. I don't know that word."

"Of course you do. My goodness. What's t-h say?"

"Thhh."

"Okay, so what is it?"

"Al-to-geth-er. Altogether!"

"Of course."

"Hmmm. Altogether, altogether. Hmmm."

It was a matter of learning the rules. I loved learning the rules-spelling, grammar, phonics.

Spelling Bees were big at my school. Regularly, usually on a Friday afternoon, we would take our places, backs to the wall around the perimeter of the classroom. Aiming at the first student in line and progressing consecutively to the last and then back to the beginning again, the teacher would fire off words from our speller, gradually picking off the unfortunates who were delivered a word they could not spell. The pressure increased in reverse proportion to the number left standing. When all but a few of us had been eliminated and those who remained standing seemed impervious to anything she sent our way, the teacher would reload with the "demon" words. It usually ended in a showdown between me and one of two classmates, and eventually one of us would take home the prize of the week. How boring and discouraging those spelling bees must have been to the poor spellers; how I loved them.

Spelling came easily to me. I never had to work at learning our weekly spelling words the way most of my classmates did. But, because at home I wanted to be seen to have homework and to struggle through it, every Thursday night after supper I would pull out my speller insisting that I had to study for the next day's test and that I needed someone to "hear my spellings." At this request everyone typically ran for cover; no one believed that my spellings needed to be heard, and no one could bear to listen to me feigning difficulty. Thursday was my 
father's bowling night so he was immediately off the hook. My mother's lack of cooperation was based on her reasoning (which was often difficult to follow) that none of us kids should need help with spelling because neither she nor our father ever did. "That's one good thing I'll say about your father, he can spell. And me, well that's one thing I was good at in school, spelling. So, according to my mother, the ability to spell had genetic origins and, since she and my father were good spellers, we must have inherited good, strong spelling genes; there was really no need for me to have my spellings heard.

My mother was sensitive, however, to my need to feel like I, like my brothers, had studying to do. She usually managed to coerce one of them into hearing my spellings. After much grumbling and complaining, and I think the occasional bribe, one of them, usually Tim, ended up with Speller in hand carelessly and begrudgingly tossing words at me from the week's list. My mother knew I knew them; Tim knew I knew them; and I certainly knew that I did. My challenge was to respond in a way that legitimated my claims about needing to study without appearing to jeopardize the family reputation of having a strong spelling gene pool. It was a balance that I was never able to strike; consequently, my efforts at having my spellings heard were short-lived.

At first I confidently returned each toss at lightning speed, striving to make a good impression. That didn't work. "Mu-u-m," Tim would yell at the top of his lungs, "Ardra's showing off. She doesn't need to study these." My next strategy was to try a "fake-out." I'd catch the word, hold it for a couple of seconds pretending with a strained quizzical look to be thinking hard, then I'd feign a return, hesitating at the last second, unsure if I was indeed correct. Finally, with a look and inflection of doubtful anticipation I'd lob back what I "hoped" was the correct spelling. "Mu-u-m, she's being a jerk! I'm not doing this anymore." I eventually gave up the plea to have my spellings heard, continued to collect my gold stars and weekly prizes, and waited for the time when my homework demands were more authentic.

In lower elementary school, as part of our regular spelling lessons, we studied phonics. We studied sound-symbol relationships and learned rules for encoding and decoding sound and letter combinations and words. We chanted mnemonic strategies such as, "When two vowels go walking, the first one does the talking", and "'i' before 'e' except after 'c' or in 'eigh' as in 'neighbour' or 'weigh."' We learned to categorize and name various combinations of vowels and consonants: short, long, and "r" controlled vowels; vowel digraphs and diphthongs (the latter for which Mrs. Davidson used to almost draw blood from her lower lip in her attempt to ensure that we learned the correct pronunciation, "Diffffff-thong. Say it, difffff-thong."); soft, hard, and nasal consonants; and consonant digraphs.

We learned rules about plurals, prefixes, and suffixes. And I loved every rote minute. But, as it was when I completed the readers in Grade 1, the joy of learning phonics came with the accomplishment of completion or acquisition, which in this case was "knowing" the rules (which either meant reciting them or applying them out of context in various rote exercises), not necessarily being able to use them to solve reading or writing problems. 
My well honed ability to learn the rules and be successful propelled me from challenge to challenge, goal to goal, task to task. Life became a series of primers to master. As with my reading primers I repeatedly set my sights on a new challenge or goal and proceeded, head bent to the task and mind's eye persistently fixed on the target ahead. And so I sped, so busy focusing on reaching each new destination I hardly even realized that I was on a journey. The goals and their realization were like power poles along a highway. I, in the driver's seat, foot bearing down on the accelerator, whizzed by each without notice. I sped past high school and my university undergraduate program. I saw, first, my teacher education program and, then, a graduate program in deaf education whiz past in a blur. In my early years of teaching, eye still on but slightly waning from the prize, I gradually became aware that my students learned in spite of me not because of me and that, despite all the rules that I had learned and all the goals accomplished, I really knew very little about what I was doing or why and who I was as teacher.

As a good girl I learned the rules and I loved learning them. I learned to conform. It was what I was most rewarded for. Perhaps that was why no one questioned my decision to become a teacher. A good girl would grow up to be a good teacher who would teach rules and conformity and would continue to behave like a good girl. And it worked...for a while, until my urge to flirt with badness and persistent quest for something more won out and I left school teaching. The values and qualities for which I had been rewarded and which allowed me to succeed as a young student, and the oppressive structures which seduced me as a young girl were the very ones that eventually turned me away from school as a young adult and teacher.

But why did it take eighteen years of formal education and several years of professional experience outside of schools for me to wake up and realize that learning was not mastering a set of primers, teaching was more than the delivery of a series of disconnected exercises, and that school was not the 'good' place I accepted it as? Why, in preparation to be a teacher, was I never asked who I was or what I thought learning was? Why was I, the teacher, and my own history and understanding of teaching, learning, and schooling never considered a relevant part of the teaching-learning relationship or the curriculum in my teacher education experience? Why is it the same for so many of the teachers I now teach?

\section{Questioning the Rules We Teach By}

In preservice teacher education classrooms, prospective teachers gather to learn about teaching or, more honestly, to learn the rules that will make them eligible to teach. They have firmly held ideas and expectations of what they need to know to be teachers; ideas and expectations rooted in their own experiences and observations of educational practices and reinforced by external forces vying to perpetuate the status quo in education and teacher education. In our education system, the collective eye-of parents, students, teachers, administrators, teacher educators, policy makers, the public-is focused on the next primer to be mastered. Teachers and learners are pressed to attend to tasks at hand-to learn 
and follow the rules. A focus on product obviates the role of the personal in teaching and learning, and renders teaching practice as partial and inauthentic.

The race to a destination precludes any acknowledgement of a journey. The demand for product wins priority over process and reinforces particular conventional notions of what counts as knowledge, what it means to teach and be a teacher, what learning is and how and where it takes place, the role of education in society, and the structures of schools, classrooms, curricula, and relationships. Despite the passage of time and the knowledge gained over that time, our school and university classrooms remain sites of inauthentic practice. In so doing education continues to be a duplicitous act of denial of the personal-an act of partial engagement, an inauthentic practice of teaching, and an inauthentic practice of learning.

The socializing forces, that serve to perpetuate the status quo in teacher education institutions and in education more generally, are strong. They assert themselves each time teachers and students gather together in school and university contexts: "What of value do I have to say about.... ?" "What does this have to do with me?" "Just tell me what to do." "What do you mean, 'Search for questions not answers'?" "But how many pages do you want?" "Enough talking, when do we get to the important stuff?" "Will this count toward my grade?" "What do you mean, 'Write for me'?" "How will all this navel gazing help me in the real world"? They assert themselves each time faculty gather to make program decisions as they parcel out: a subject-based curriculum according to credit hours and territorial markers, preservice teachers to whatever schools will take them for the designated number of practicum days required for certification eligibility, and grades according to some standardized accountability criteria.

Large enrolment and class sizes, the physical structure of most university classrooms, class and course schedules which arrange insufficiently frequent class meetings, program structures that deny access to certain segments of the population, fragmented programs and curricula which are often rigidly defined, orientations held by students and fostered by institutions (schools and universities) that reflect conservative and technical views of teaching and learning, and an adherence to government-directed policies that have little to do with education and a lot to do with bottom line politics all work together to shape the grand narrative of education.

In two recently completed studies of teacher education reform in Canadian universities I explored the experiences and processes of those attempting to construct a counternarrative of teacher education. The institutional forces militating against such an agenda are strong. One of the persistent and pervasive findings in both studies is that, despite rhetoric to the contrary, there really is very little collective will to support a reform agenda. Efforts to challenge the norms that continue to govern and define teacher education as a site of inauthentic practice are consistently overpowered by status quo structures and perspectives. 


\section{Conclusion}

A curriculum and pedagogy of reflexive inquiry has the power to transform, deepen, and broaden conceptions of teacher education and to really make a difference in how teachers see and express themselves in educational contexts. But, if that potential is to be realized, we need to understand and attend to the sociopolitical context within which such a reconstruction takes place and to collectively act on the forces that keep students, teachers, and teacher educators learning and following the rules.

\section{References}

Cole, A. L., \& Knowles, J. G. (2000). Researching Teaching: Exploring Teacher Development through Reflexive Inquiry. Boston: Allyn \& Bacon.

Knowles, J. G., \& Cole, A. L. with Presswood, C. S. (1994). Through Preservice Teachers' Eyes: Exploring Field Experiences through Narrative and Inquiry. New York: Merrill.

Paley, V. G. (1989). Foreword. In W. Ayers, The Good Preschool Teacher. New York: Teachers College Press.

Pinar, W. F. (1981). Whole, bright, deep with understanding: Issues in qualitative research and autobiographical method. Journal of Curriculum Studies, 13(3), 173- 188.

Both studies mentioned above were funded by the Social Sciences and Humanities Research Council of Canada. The first is entitled, "Canadian Preservice Teacher Educators and the Reform of Teacher Education: A Life History Study" and the second, "Case Studies of Reform in Canadian Preservice Teacher Education”. 
